\title{
PEMASARAN BAWANG MERAH DI DESA TONSEWER SELATAN KECAMATAN TOMPASO BARAT
}

\author{
Lasmaria Elisabet Marbun \\ Juliana R. Mandei \\ Ribka M. Kumaat
}

\begin{abstract}
This study aims to analyze marketing channels and the efficiency of onion marketing in South Tonsewer Village, West Tompaso Sub-District. The data used are primary data and secondary data. Primary data is obtained through a list of questions that have been prepared while secondary data obtained from BP3K Office District West Tompaso, BPS (Central Statistics Agency), Internet and previous research on Marketing. Farmer samples were collected using Simple Random Sampling method and for marketing institution using snowball sampling method. The number of samples of farmers is 25 people. The data are presented in tabular form and then analyzed descriptively. The concept of measurement of variables used is the selling price, the number of onion and marketing costs. The results showed that marketing channels in Tonsewer Selatan Village, Tompaso Barat District consisted of 4 (1) farmers - Kawangkoan market retailers - consumers, (2) farmers - seller retailers Langowan market - consumers, (3) farmers - collectors village - Tomohon market-consumer merchants, and (4) farmers - village wholesalers - wholesalers of Bitung port - consumers. Based on the value of price transmission elasticity, marketing margin, farmer's share, and profit-to-cost ratio indicate that four marketing channels are not efficient. an efficient marketing channel based on the value of price transmission elasticity, marketing margins, and farmer's share, two efficient marketing channels based on farmer's share and cost-benefit ratios, and three efficient marketing channels at farmer's share.
\end{abstract}

Keywords: onion marketing, South Tonsewer Village, West Tompaso Sub-District

\begin{abstract}
ABSTRAK
Penelitian ini bertujuan untuk menganalisis saluran pemasaran dan efesiensi pemasaran bawang merah di Desa Tonsewer Selatan Kecamatan Tompaso Barat. Data yang digunakan yaitu data primer dan data sekunder. Data primer diperoleh melalui daftar pertanyaan yang telah disiapkan sedangkan data sekunder diperoleh dari Kantor BP3K Kecamatan Tompaso Barat, BPS (Badan Pusat Statistika), Internet dan Penelitian terdahulu tentang Pemasaran. Penarikan sampel petani dilakukan dengan menggunakan metode Simple Random Sampling dan untuk lembaga pemasaran menggunakan metode snowball sampling. Jumlah sampel petani sebanyak 25 orang. Data disajikan dalam bentuk tabel kemudian dianalis secara deskriptif. Konsep pengukuran variabel yang digunakan adalah harga jual, jumlah bawang merah dan biaya-biaya pemasaran. Hasil penelitian menunjukan bahwa saluran pemasaran yang terjadi di Desa Tonsewer Selatan Kecamatan Tompaso Barat terdiri dari 4 yaitu (1) petani - pedagang pengecer pasar Kawangkoan - konsumen, (2) petani - pedagang pengecer pasar Langowan - konsumen, (3) petani - pedagang pengumpul desa - pedagang pengecer pasar Tomohon - konsumen, dan (4) petani - pedagang besar desa - pedagang besar pelabuhan Bitung - konsumen. Berdasarkan nilai elastisitas transmisi harga, margin pemasaran, farmer's share, dan rasio keuntungan terhadap biaya menunjukkan bahwa saluran pemasaran empat tidak efesien. saluran pemasaran satu efesien berdasarkan nilai elastisitas transmisi harga, margin pemasaran, dan farmer's share, saluran pemasaran dua efesien berdasarkan farmer's share dan rasio keuntungan terhadap biaya, dan saluran pemasaran tiga efesien pada farmer's share.
\end{abstract}

Kata kunci: pemasaran bawang merah, Desa Tonsewer Selatan, Kecamatan Tompaso Barat 


\section{PENDAHULUAN}

\section{Latar Belakang}

Indonesia sebagai negara yang memiliki kekayaan sumber daya (resource endowment) dan beriklim tropis sehingga dapat menghasilkan berbagai produk pertanian, diantaranya komoditas hortikultura terutama sayuran dan buah-buahan. Salah satu produk pertanian dari komoditas sayuran adalah bawang merah. Usahatani bawang merah layak diusahakan dan menguntungkan. Keuntungan yang didapat pun termasuk tinggi yaitu sekitar $45 \%$ dari total biaya, Setiap pengeluaran biaya Rp.1.000,00 akan menghasilkan keuntungan sebesar Rp.450,00 (Sudarmanto, 2016 ).

Kabupaten Minahasa ada beberapa kecamatan yang memproduksi tanaman bawang merah, salah satunya adalah Kecamatan Tompaso Barat. Berikut ini tabel yang menunjukkan luas panen dan produksi bawang merah dari masing-masing Kecamatan di Kabupaten Minahasa.

Tabel 1. Luas Panen dan Produksi Bawang Merah Pada Setiap Kecamatan di Kabupaten Minahasa Tahun 2016

\begin{tabular}{lcc}
\hline Kecamatan & $\begin{array}{c}\text { Harvest Area } \\
\text { (Ha) }\end{array}$ & $\begin{array}{c}\text { Production } \\
\text { (ton) }\end{array}$ \\
\hline Langowan Barat & 25 & 212 \\
Langowan Selatan & 17 & 144 \\
Tompaso & 87 & 736 \\
Tompaso Barat & 102 & 863 \\
Kawangkoan Barat & 17 & 144 \\
Kawangkoan & 7 & 59 \\
Tondano Barat & 8 & 68 \\
\hline
\end{tabular}

Sumber: Badan Pusat Statistik, 2017

Tabel 1 menunjukkan bahwa Kecamatan Tompaso Barat memproduksi bawang merah tertinggi yaitu sebesar 863 ton dengan luas panen sebesar 102 per hektar. Desa Tonsewer Selatan merupakan salah satu desa yang menjadi sentra produksi bawang merah dilihat dari luas tanam, luas panen dan produksi bawang merah di Kecamatan Tompaso Barat. Berikut ini tabel yang menunjukkan luas tanam, luas panen dan produksi bawang merah di kecamatan Tompaso Barat Tahun 2016.

\begin{tabular}{|c|c|c|c|c|}
\hline Desa & $\begin{array}{c}\text { Luas } \\
\text { Tanam } \\
\text { (Ha) }\end{array}$ & $\begin{array}{c}\text { Luas } \\
\text { Panen } \\
\text { (Ha) }\end{array}$ & $\begin{array}{l}\text { Produksi } \\
\text { (Ton) }\end{array}$ & $\begin{array}{c}\text { Rata-rata Produksi } \\
\text { (Ton/Ha) }\end{array}$ \\
\hline Pinabetengan Utara & 3 & 3 & 18,3 & 6,1 \\
\hline Pinabetengan Selatan & 4 & 4 & 25,2 & 6,3 \\
\hline Tonsewer & 33 & 33 & 264 & 8.0 \\
\hline Touure & 7,5 & 7,5 & 48 & 6,8 \\
\hline Tonsewer Selatan & 35 & 35 & 280 & 8,0 \\
\hline Touree II & 5 & 5 & 32 & 6,8 \\
\hline
\end{tabular}

Tabel 2 menunjukkan bahwa jumlah produksi bawang merah terbanyak terdapat di Desa Tonsewer Selatan yang mempunyai jumlah produksi 280 ton per tahundengan produktivitas sebesar 8,0 ton perhektar. Desa Tonsewer Selatan mempunyai varietas bawang merah yang ungul yaitu varietas "Lansuna". Sebagai varietas unggulan sekaligus menjadi andalan di Desa Tonsewer Selatan, bawang merah jenis ini mempunyai ciri khas yang berbeda dari bawang merah lainnya seperti berukuran lebih besar dan memiliki warna yang lebih merah serta bisa ditanam kapan saja tanpa mengenal musim. Oleh sebab itu Bawang merah khas Tonsewer Selatan sering menjadi ikon bawang merah pada setiap pameran di daerah maupun di provinsi SULUT (Sulawesi Utara) bahkan sudah diperkenalkan hingga ke luar kota seperti ikut PENAS (Pekan Nasional) petani nelayan Tahun 2014 di Malang.

Permasalahan yang sering dihadapi dalam pemasaran bawang merah adalah margin pemasaran yang terlalu besar akibat saluran pemasaran yang panjang maka harga yang diterima produsen semakin kecil yang dapat mengindikasikan rendahnya balas jasa atau bagian harga yang diterima petani, selainnya itu lemahnya posisi tawar yang rendah akibat over supply yang terjadi pada panen raya sehingga menyebabkan rendahnya harga yang diterima petani (Rahayu, 2009).

Produksi bawang merah di Desa Tonsewer Selatan dijual untuk menambah pendapatan keluarga dan sebagian kecil untuk konsumsi rumah tangga. Produksi bawang merah dari Desa Tonsewer Selatan Kecamatan Tompaso Barat tidak hanya dipasarkan di dalam melainkan dipasarkan diluar Kecamatan Tompaso Barat seperti 
pasar Tomohon dan sampai ke Kota Timika. Pemasaran bawang merah di Desa Tonsewer Selatan dilakukan oleh pedagang dalam Desa Tonsewer Selatan dan oleh pedagang dari luar Desa Tonsewer Selatan. Pedagang pengumpul mendistribusikan bawang merah kepada pedagang pengecer di pasar Tomohon. Selain itu, ada juga petani yang menjual kepada pedagang pengecer di pasar Kawangkoan dan Langowan, ada juga pedagang besar desa yang menjual ke Kota Timika melalui pelabuhan Bitung. Pemasaran dari dalam Desa Tonsewer Selatan dilakukan berdasarkan sifat kekeluargaan, sehingga pola saluran pemasaran yang ditempuh belum memperhatikan aspek keuntungan. Dalam meningkatkan pendapatan petani maka harus ditunjang dengan harga pasar dan system pemasaran yang efesien agar arus distibusi bawang merah dari produsen ke konsumen berjalan dengan baik. Pemasaran dapat dikatakan efesien apabila tercipta keadaan dimana semua lembaga pemasaran yang terlibat didalamnya memperoleh kepuasan dengan aktivitas pemasaran tersebut.

Berdasarkan uraian diatas maka perlu di lakukan penelitian tentang pemasaran bawang merah di Desa Tonsewer Selatan yang bertujuan untuk menganalisis nilai farmer's share, margin pemasaran, rasio keuntungan terhadap biaya, elastisitas transmisi harga dan saluran pemasaran bawang merah di Desa Tonsewer Selatan Kecamatan Tompaso Barat Kabupaten Minahasa. Sehingga dapat memperhitungkan pengembangan pemasaran usahatani bawang merah secara optimal.

\section{Rumusan Masalah}

Adapun yang menjadi rumusan masalah adalah sebagai berikut :

1. Bagaimana saluran pemasaran bawang merah di Desa Tonsewer Selatan?

2. Bagaimana efisiensi pada setiap saluran pemasaran bawang merah dilihat dari elastisitas transmisi harga, margin pemasaran, Farmer's Share dan rasio keuntungan terhadap biaya di Desa Tonsewer Selatan?

\section{Tujuan Penelitian}

Adapun yang menjadi tujuan penelitian adalah sebagai berikut :

1. Untuk mengetahui saluran pemasaran bawang merah di Desa Tonsewer Selatan.

2. Untuk mengetahui efesiensi pada setiap saluran pemasaran dilihat dari elastisitas transmisi harga distribusi margin, Farmer's Share dan rasio keuntungan terhadap biaya di Desa Tonsewer Selatan.

\section{Manfaat Penelitian}

1. Sebagai bahan informasi bagi petani bawang merah dalam memilih saluran yang dapat lebih menguntungkan.

2. Sebagai bahan informasi bagi pemerintah dan para pengambil keputusan dalam pengembangan pemasaran bawang merah.

3. Sebagai sarana bagi penulis untuk melatih kemampuan dalam menganalisa masalah berdasarkan fakta dan data yang tersedia yang disesuaikan dengan pengetahuan yang diperoleh selama kuliah.

4. Sebagai informasi bagi peneliti lainnya yang berhubungan dengan penelitian ini.

\section{METODOLOGI PENELITIAN}

\section{Waktu dan Tempat Penelitian}

Penelitian dilaksanakan selama tiga bulan yaitu dimulai dari bulan Oktober sampai bulan Desember yang berlokasi di Desa Tonsewer Selatan Kecamatan Tompaso Barat Kabupaten Minahasa yang merupakan sentra produksi bawang merah.

\section{Metode Pengumpulan Data}

Jenis data yang diambil adalah data primer dan sekunder.Data primer bersumber dari masing-masingdalam saluran pemasaran dengan menggunakan metode kuesioner diisi langsung oleh peneliti sesuai dengan hasil wawancara yang diperoleh dari responden dengan bentuk daftar pertanyaan. Data sekunder dalam penelitian ini bersumber dari Badan Pusat Statistik (BPS), internet, Penelitian terdahulu dan BP3K kecamatan Tompaso Barat. 


\section{Teknik Pengambilan Sampel}

Penentuan lokasi penelitian dilakukan secara sengaja (Purposive Sampling) yaitu di Desa Tonsewer Selatan. Responden yang diambil adalah petani, pedagang pengumpul, pedagang besar, dan pedagang pengecer. Penarikan sampel petani bawang merah di Desa Tonsewer Selatan dilakukan secara simple random sampling atau secara acak sederhana yaitu pengambilan sampel petani yang sedang melakukan panen.

Pengambilan sampel lembaga pemasaran (pengumpul, pedagang besar, dan pedagang pengecer) ditentukan dengan metode bola salju (snowball sampling). Metode snowball sampling yaitu teknik menentukan responden secara berantai dengan meminta informasi pada orang yang telah diwawancarai atau dihubungi sebelumnya dan seperti itu seterusnya.

\section{Konsepsi Pengukuran Variabel}

Adapun variabel yang diukur dalam penelitian ini pada satu kali periode produksi bawang merah adalah:

1. Harga jual; harga penjualan bawang merah di setiap lembaga pemasaran yang dinyatakan dalam satuan $\mathrm{Rp} / \mathrm{kg}$.

2. Volume penjualan; jumlah bawang merah yang dijual di setiap lembaga pemasaran yang dinyatakan dalam satuan kilogram.

3. Biaya pengangkutan; biaya transportasi atau ongkos bawang merah dari produsen (petani) ke konsumen yang dinyatakan dalam dalam $\mathrm{Rp} / \mathrm{Kg}$.

4. Biaya bongkar muat; biaya tenaga kerja pemindahan bawang merah yang ada dimobil dan dikapal yang dinyatakan dalam $\mathrm{Rp} / \mathrm{Kg}$.

5. Biaya sortasi; biaya untuk penggolongan bawang merah dan pengepakan dinyatakan dalam Rp/Kg.

6. Biaya penjemuran; biaya untuk tenaga kerja penjemuran dan pengeringan bawang merah sebelum didistribusikan dinyatakan dalam $\mathrm{Rp} / \mathrm{Kg}$.

7. Biaya pengemasan; biaya untuk pembelian karung dan kantong plastik bawang merah dinyatakan dalam $\mathrm{Rp} / \mathrm{Kg}$.
8. Retribusi; biaya iuran dipasar oleh setiap lembaga pemasaran kepada pemerintah dinyatakan dalam $\mathrm{Rp} / \mathrm{Kg}$.

9. Penyimpanan; biaya penampungan bawang merah sebelum didistribusikan kepada konsumen dinyatakan dalam $\mathrm{Rp} / \mathrm{Kg}$.

\section{Metode Analisis Data}

Untuk menentukan saluran pemasaran pendekatan yang digunakan untuk mengetahui saluran pemasaran adalah pendekatan langsung. Saluran pemasaran bawang merah di Desa Tonsewer Selatan Kecamatan Tompaso Barat, Kabupaten Minahasa dapat diketahui dengan mengikuti aliran pemasaran bawang merah dari petani produsen sampai ke konsumen akhir. Setelah diperoleh data primer, maka dapat diketahui bagaimana efisiensi pemasaran bawang merah dan besarnya efisiensi masingmasing saluran pemasaran di Kecamatan Tompaso barat, Kabupaten Minahasa.

Dalam penelitian ini metode yang digunakan untuk mengetahui efisiensi pemasaran bawang merah di Desa Tonsewer Selatan adalah elastisitas transmisi harga, margin pemasaran, farmer's share, dan rasio keuntungan terhadap biaya.

\section{Elastisitas Transmisi Harga}

Menurut Indhiani Abubakar (2016), untuk mengetahui elastisitas transmisi dapat menggunakan rumus tersebut:

Keterangan :

$$
E t=\frac{1}{b} X \frac{P f}{P r}
$$

$$
\begin{aligned}
& \text { Et }=\text { Elastisitas transmisi harga } \\
& \mathrm{b}=\text { Koefisien regresi atau slope } \\
& \text { Pf }=\text { Harga di tingkat produsen } \\
& \operatorname{Pr}=\text { Harga di tingkat konsumen }
\end{aligned}
$$

\section{Margin pemasaran}

Menurut Anindita (2017), secara matematitis margin pemasaran dapat dirumuskan sebagai berikut:

$$
\begin{aligned}
\text { Keterangan } & \text { : } \\
\mathrm{Mp} & =\text { margin pemasaran } \\
\mathrm{Pf} & =\text { harga ditingkat produsen } \\
\mathrm{Pr} & =\text { harga ditingkat konsumen akhir }
\end{aligned}
$$$$
M p=P r-P f
$$ 


\section{Farmer's Share}

Untuk menghitung farmer's share menurut Azzaino (1987), digunakan perhitungan dengan rumus :

$$
\begin{aligned}
\mathrm{FS}= & \text { Farmer's Share } \\
\mathrm{HP}= & \text { Harga jual bawang merah } \\
& (\mathrm{Rp} / \mathrm{Kg}) \\
\mathrm{HK}= & \text { Harga beli Konsumen } \\
& (\mathrm{Rp} / \mathrm{Kg})
\end{aligned}
$$

Keterangan:

$$
F S=\frac{H P}{H K} \times 100 \%
$$

\section{Rasio Keuntungan Terhadap Biaya}

Menurut Rahmawati (2013), efesiensi pemasaran juga dapat dilihat dengan persentase keuntungan terhadap biaya ( $\mathrm{P} / \mathrm{C}$ rasio) pada setiap lembaga pemasaran yang dikeluarkan pada masing-masing saluran pemasaran, rumus yang digunakan yaitu:

Dimana:

$$
\frac{\mathrm{P}}{\mathrm{C}} \text { rasio }=\frac{\pi i}{C i}
$$

$\pi \mathrm{i}=$ Keuntungan lembaga pemasaran

$\mathrm{ci}=$ Biaya lembaga pemasaran

\section{HASIL DAN PEMBAHASAN}

\section{Deskripsi Daerah Penelitian}

\section{Letak Geografis dan Luas Wilayah}

Desa Tonsewer Selatan adalah sebuah desa yang terletak di wilayah kecamatan Tompaso Barat, Kabupaten Minahasa, Provinsi Sulawesi Utara yang terdiri dari empat jaga dengan batas wilayah :

Sebelah Utara : Desa Tonsewer

Sebelah Bara : Desa Touure Dua

Sebelah Selatan : Hutan lindung Kalelondey

Sebelah Timur : Desa Pinabetengan Selatan

Ketinggian antara 500-750 meter diatas permukaan laut serta pengaruh gunung berapi yitu gunung soputan sangat menunjang kesuburan tanah dikawasn ini sehingga baik dipergunakan untuk mengusahakan berbagai komoditas pertanian termasuk didalamnya bawang merah.
Luas wilayah desa Tonsewer Selatan adalah kurang lebih $125 \mathrm{Ha}$. Kecamatan ini berjarak 2,5 $\mathrm{Km}$ dari pusat pemerintahan kecamatan (Tompaso Barat), dan $28 \mathrm{Km}$ dari pusat pemerintahan kabupaten (Minahasa), dan berjarak $51 \mathrm{Km}$ dari pusat pemerintahan Provinsi (Manado).

\section{Jumlah Penduduk}

Penduduk di Kecamatan Tompaso Barat berjumlah 11.674 jiwa, yang mencakup penduduk yang bertempat tinggal tetap dan tidak tetap. Desa Tonsewer Selatan memiliki jumlah penduduk 847 jiwa, yang tersebar dalam empat wilayah jaga. Jumlah penduduk laki-laki 440 jiwa dan jumlah penduduk perempuan 407 jiwa. Keluarga di Kecamatan Tompaso Barat berjumlah yakni 3.213 KK.

\section{Mata Pencarian}

Tingkat perekonomian Desa Tonsewer Selatan umumnya ditentukan oleh sektor pertanian. Sebagai mata pencarian adalah bertani yang berkisar 95 persen dan sisa 5 persennya adalah jenis pekerjaan lainnya sebagai peternak, pegawai negeri sipil, swasta dan pedagang. Tanaman hortikultura yang paling banyak ditanam oleh petani di Desa Tonsewer Selatan yaitu bawang merah, hampir semua penduduk membudidayakan bawang merah.

\section{Karakteristik Responden Petani}

\section{Tingkat Umur}

Berdasarkan UU Ketenagakerjaan no. 13 tahun 2003 mengenai usia produktif untuk bekerja yaitu mereka yang berusia antara 15 tahun sampai dengan 64 tahun. Cara berpikir dan kemampuan fisik petani sangat dipengaruhi oleh tingkat umur, secara fisik semakin tinggi umur petani maka semakin kurang kemampuan dalam bekerja, sedangkan petani yang berusia produktif pada umumnya mempunyai kemampuan fisik dan cara berpikir yang baik. Umur petani responden dapat dilihat pada Tabel 3. 
Tabel 3. Jumlah Petani Responden di Desa Tonsewer Selatan

\begin{tabular}{cccc}
\hline No & $\begin{array}{c}\text { Umur } \\
\text { (Tahun) }\end{array}$ & $\begin{array}{c}\text { Jumlah } \\
\text { Responden }\end{array}$ & $\begin{array}{c}\text { Persentase } \\
(\%)\end{array}$ \\
\hline 1 & $30-40$ & 13 & 52 \\
2 & $41-50$ & 9 & 36 \\
3 & $51-60$ & 3 & 12 \\
\hline & Jumlah & 25 & 100 \\
\hline
\end{tabular}

Sumber : Data Primer yang Diolah, 2017

Tabel 3 menunjukkan bahwa responden petani berumur produktif. Hal ini dilihat dari jumlah petani (responden) dengan usia pada interval 30-40 tahun sebanyak 13 (tiga belas) orang (52\%), 41-50 tahun sebanyak 9 (Sembilan) orang (36\%) dan interval 51-60 tahun sebanyak 3 (tiga) orang (12\%).

\section{Tingkat Pendidikan}

Pendidikan adalah alat untuk mengembangkan diri, mental, pola pikir, dan kualitas diri seseorang. Makin tinggi pendidikan seorang petani maka makin tinggi pula tingkat kecakapan petani dalam menjalankan tugas dan fungsinya dalam bekerja. Tingkat pendidikan petani (responden) dapat dilihat pada Tabel 4.

\begin{tabular}{|c|c|c|c|}
\hline Tabe & $\begin{array}{l}\text { Tir } \\
\text { Re } \\
\text { Se }\end{array}$ & $\begin{array}{l}\text { Pendid } \\
\text { nden di D } \\
\text { n }\end{array}$ & $\begin{array}{r}\text { Petani } \\
\text { Tonsewer }\end{array}$ \\
\hline No & $\begin{array}{c}\text { Tingkat } \\
\text { pendidikan }\end{array}$ & $\begin{array}{l}\text { Jumlah } \\
\text { responden } \\
\text { (orang) }\end{array}$ & $\begin{array}{c}\text { Persentase } \\
(\%)\end{array}$ \\
\hline 1 & SD & 9 & 36 \\
\hline 2 & SMP & 5 & 20 \\
\hline 3 & SMA & 11 & 44 \\
\hline & Jumlah & 25 & 100 \\
\hline
\end{tabular}

Sumber : Data Primer yang Diolah, 2017

Tabel 4 menunjukan bahwa tingkat pendidikan petani tertinggi berada pada tingkat pendidikan SMA dengan jumlah petani responden 11 orang sedangkan tingkat SMP yaitu $36 \%$ dengan jumlah responden 5 orang kemudian pada tingkat SD yaitu $20,00 \%$ dengan jumlah petani responden 9 orang . Maka dapat dikatakan bahwa tingkat pendidikan petani bawang merah di Desa
Tonsewer Selatan Kecamatan Tompaso Barat cukup relatif, karena sebagian besar petani responden pernah menempuh pendidikan meskipun berada pada tingkat yang berbeda.

\section{Pengalaman Berusahatani}

Semakin lama pengalaman usahatani petani maka akan semakin baik proses pengalokasian faktor-faktor produksi sehingga usahatani akan semakin baik. Pengalaman usahatani juga berpengaruh terhadap pengetahuan dan keterampilan petani dalam mengalokasikan faktor produksi dalam penerapan suatu teknologi baru. Apabila pengalaman yang dimiliki petani semakin banyak maka akan dapat mendorong petani untuk menerapkan teknologi baru yang berguna untuk mendapatkan hasil yang lebih baik. Pengalaman petani dalam berusahatani bawang merah di Desa Tonsewer Selatan dapat dilihat pada Tabel 5.

Tabel 5. Pengalaman Berusahatani Petani Sampel di Desa Tonsewer Selatan

\begin{tabular}{cccc}
\hline No & $\begin{array}{c}\text { Pengalaman Usahatani Bawang } \\
\text { Merah(Tahun) }\end{array}$ & Jumlah Responden & $\begin{array}{c}\text { Persentase } \\
(\%)\end{array}$ \\
\hline 1 & $4-14$ & 13 & 52,00 \\
2 & $15-25$ & 11 & 44,00 \\
3 & $>25$ & 1 & 4,00 \\
\hline Total & 25 & 100 \\
\hline Sumber : Data Primer yang Diolah, 2017 & &
\end{tabular}

Berdasarkan pada Tabel 5 dapat dilihat lama pengalaman usahatani responden petani bawang merah berkisar 4-26 tahun. Petani yang menjalankan usahatani bawang merah selama 4-14 tahun sebanyak 13 orang atau $52,00 \%$ sedangkan sebanyak 11 orang petani menjakankan usahatani bawang merah selama 15-25 orang atau 44,00\% dan untuk 1 orang petani dengan persentase terkecil yaitu $4,00 \%$ telah menjalankan usahatani selama $>25$ tahun. Penduduk di Desa Tonsewer Selatan Kecamatan Tompaso Barat pada umumnya telah lama menjalankan usahatani bawang merah ini bahkan sudah sebagai mata pencarian yang turun temurun walaupun harga jual bawang merah yang berfluktuasi. 


\section{Karakteristik Responden Lembaga Pemasaran Bawang Merah}

\section{Tingkat Umur}

Umur petani memiliki hubungan dengan kemampuan petani dalam bekerja.Jika ditinjau dari segi fisik, semakin tua umur seseorang setelah melewati batas umur tertentu, maka semakin berkurang kemampuan untuk bekerja. Umur merupakan salah satu faktor yang mempengaruhi cepat lambatnya kinerja pedagang. Usia pedagang bawang merah dapat dilihat pada Tabel 6 .

\begin{tabular}{ccccccccc} 
Tabel 6. Usia Pedagang Responden Bawang Merah Tahun 2017 \\
$\begin{array}{c}\text { Kelompok } \\
\text { Umur }\end{array}$ & $\begin{array}{c}\text { Petani } \\
\text { Pedagang }\end{array}$ & \multicolumn{2}{c}{$\begin{array}{c}\text { Pedagang } \\
\text { Pengumpul }\end{array}$} & $\begin{array}{c}\text { Pedagang } \\
\text { Besar }\end{array}$ & \multicolumn{2}{c}{$\begin{array}{c}\text { Pedagang } \\
\text { Pengecer }\end{array}$} \\
\cline { 2 - 9 } (Tahun) & Jumlah & $\%$ & Jumlah & $\%$ & Jumlah & $\%$ & Jumlah & $\%$ \\
\hline $31-36$ & 1 & 25,00 & 2 & 20,00 & - & - & 2 & 14,28 \\
$37-42$ & 3 & 75,00 & 3 & 40,00 & - & - & 3 & 21,43 \\
$43-48$ & - & & 2 & 10,00 & - & - & 3 & 21,43 \\
$49-54$ & - & & 2 & 10,00 & 1 & 100 & 6 & 42,86 \\
$55-60$ & - & & 1 & 20,00 & - & & 2 & 12,5 \\
\hline Jumlah & 4 & 100 & 10 & 100 & 1 & 100 & 16 & 100 \\
\hline
\end{tabular}

Berdasarkan Tabel 6 umur petani pedagang berada pada usia 31-36 tahun berjumlah 1 orang dan sebanyak 3 orang berada pada usia 37-42 tahun. Responden pedagang pengumpul berada pada umur 31-36 tahun berjumlah 4 orang atau persentase $20 \%$ sedangkan sebanyak delapan orang berada pada usia 37-42 tahun dan untuk usia 43-60 tahun berjumlah 8 orang. Usia Pedagang besar yaitu 47 tahun. Pedagang pengecer berjumlah 14 orang berada pada usia 31-54 tahun. Dapat dilihat bahwa pedangang bawang merah berada pada usia produktif sehingga diharapkan dengan usia yang masih produktif dapat memberikan kontribusi pemikiran dan fisik yang baik dalam menjalankan usahanya.

\section{Tingkat Pendidikan}

Tingkat pendidikan yang dimiliki pedagang sangat berpengaruh terhadap daya nalar dan pola pikir serta sikap dan perilaku seseorang. Tingkat pendidikan dapat memberikan variasi tersendiri dalam berpikir, bersikap dan bertindak dalam mengambil keputusan dan melakukan perhitungan laba dan rugi demi kelancaran usaha yang sedang dilakukan. Tingkat pendidikan pedagang dapat dilihat pada Tabel 7.
Tabel 7. Tingkat Pendidikan Pedagang

\begin{tabular}{lccc}
\hline No & $\begin{array}{c}\text { Tingkat } \\
\text { Pendidikan }\end{array}$ & $\begin{array}{c}\text { Jumlah } \\
\text { (Jiwa) }\end{array}$ & $\begin{array}{c}\text { Persentase } \\
(\%)\end{array}$ \\
\hline 1 & SD & 5 & 18,51 \\
2 & SMP/SLTP & 7 & 25,92 \\
3 & SMA/SLTA & 15 & 55,55 \\
\hline & Jumlah & 27 & 100 \\
\hline
\end{tabular}

Sumber : Data Primer yang Diolah, 2017

Berdasarkan Tabel 7 pendidikan pedagang bawang merah berada pada tingkat pendidikan formal yang baik, dimana pedagang tingkat pendidikan SMA/SLTA terbanyak, yakni sebanyak 15 jiwa dengan persentase $55,55 \%$ dengan pendidikan pedagang demikian diharapkan dapat mempengaruhi daya serap sehingga dapat mengikuti informasi pasar mengenai harga bawang merah dengan baik.

\section{Pengalaman Berdagang}

Pengalaman berdagang dapat mempengaruhi cara dan keahlian berdagang bawang merah, Misalnya menentukan volume penjualan, kerjasama antar petani dan pedagang serta kecepatan memperoleh informasi pasar. Lamanya pengalaman berdagang pedagang bawang merah dapat dilihat pada Tabel 8 .

\begin{tabular}{ccccccccc}
\multicolumn{2}{c}{ Tabel 8. Pengalaman Pedagang Berdagang Bawang Merah Tahun 2017 } \\
\hline $\begin{array}{c}\text { Pengalaman } \\
\text { Berdagang } \\
\text { (Tahun) }\end{array}$ & $\begin{array}{c}\text { Petani } \\
\text { Pedagang }\end{array}$ & \multicolumn{2}{c}{$\begin{array}{c}\text { Pedagang } \\
\text { Pengumpul }\end{array}$} & $\begin{array}{c}\text { Pedagang } \\
\text { Besar }\end{array}$ & \multicolumn{2}{c}{$\begin{array}{c}\text { Pedagang } \\
\text { Pengecer }\end{array}$} \\
\cline { 2 - 10 } & Jumlah & $\%$ & Jumlah & $\%$ & Jumlah & $\%$ & Jumlah & $\%$ \\
\hline $1-5$ & - & - & 3 & 30,00 & - & - & 4 & 25,00 \\
$6-10$ & - & - & 6 & 60,00 & 1 & 100 & 8 & 50,00 \\
$11-15$ & 1 & 25,00 & 1 & 10,00 & - & - & 3 & 18,75 \\
$16-20$ & 3 & 75,00 & - & - & - & - & 1 & 6,25 \\
\hline Jumlah & 4 & 100 & 10 & 100 & 1 & 100 & 16 & 100 \\
\hline Sumber : Data Primer yang Diolah, 2017 & & & &
\end{tabular}

Berdasarkan Tabel 8 Pengalaman dan lamanya dalam menekuni profesi sebagai petani pedagang responden yaitu $>15$ tahun untuk empat responden. Pengalaman berusaha dari pedagang pengumpul responden yaitu yang sudah menekuni pekerjaan ini selama $>5$ tahun sebanyak dua puluh (6) orang dan pedagang besar yang telah menekuni pekerjaan ini selama sembilan tahun yaitu satu orang pedagang responden. Sebanyak 8 orang pengecer yang menekuni pekerjaan ini selama $>5$ tahun. 


\section{Pemasaran Bawang Merah \\ di Desa Tonsewer Selatan \\ Kecamatan Tompaso Barat}

Pemasaran bawang merah merupakan kegiatan penyampaian komoditi bawang merah dari petani ke konsumen dengan tujuan mendapatkan nilai uang sebagai balas jasa atas hasil komoditinya. Pemasaran bawang merah dilakukan petani setelah melalui penjemuran dan pengeringan selama satu minggu atau lebih tergantung keadaan cuaca. Penjemuran bawang merah tidak dapat terlalu lama dibawah terik matahari, hanya dapat dijemur sekitar dua jam menggunakan terpal lalu dilakukan penyimpanan seperti digantung/diletakkan diatas rak-rak.

Sistem penjualan yang terjadi pada komoditi bawang merah di Desa Tonsewer Selatan ada tiga sistem yaitu pertama secara lansung produsen (petani) lansung memasarkan kepada pedagang pengecer yang ada di pasar lokal seperti pasar Langowan dan Kawangkoan. Kedua melalui perantara yaitu pedagang pengumpul yang ada di Desa Tonsewer Selatan membeli bawang merah dari petani kemudian menjualnya kepada pedagang pengecer yang ada di pasar Tomohon, kemudian pedagang pengecer menjual bawang merah di pasar tersebut pada hari pasar Tomohon. Ketiga pedagang besar desa membeli bawang merah kepada petani kemudian mendistribusikan ke pelabuhan Pomako Timika melalui pelabuhan Bitung.

Pemasaran bawang merah di Desa Tonsewer Selatan dipasarkan per "keranjang", dan ukuran satu keranjang penuh yaitu $12 \mathrm{~kg}$. Bawang merah yang akan dijual dikemas kedalam karung dan harga karung Rp.3.000, ukuran satu karung yaitu $50 \mathrm{~kg}$. Biaya angkutan yang dikeluarkan kepasar Langowan dan Kawangkoan yang menggunakan motor (ojek) yaitu Rp.10.000 per $80 \mathrm{~kg}$, kepasar Tomohon Rp.8.000 per $40 \mathrm{~kg}$ menggunakan mobil pick up, dari pusat produksi ke pelabuhan Bitung Rp.15.000 per $60 \mathrm{~kg}$ menggunakan truk, dari pelabuhan Bitung ke pelabuhan Pomako Timika Rp. 120.000 per 60 kg menggunakan transportasi kapal laut.

\section{Lembaga Pemasaran Bawang Merah}

Sistem pemasaran bawang merah di Desa Tonsewer Selatan tidak lepas dari peran lembaga-lembaga pemasaran yang mengambil bagian dalam kegiatan pemasaran. Lembaga pemasaran terdiri atas petani, pedagang pengumpul desa, pedagang besar, pedagang pengecer dan konsumen. Masing-masing lembaga pemasaran mempunyai peranan penting dalam pemasaran bawang merah.

1) Petani

Petani merupakan produsen bawang merah yang mengawali pemasaran bawang merah di Desa Tonsewer Selatan. Hasil penelitian menunjukkan bahwa ada dua puluh lima orang petani yang menjadi sampel, petani yang melakukan panen kemudian memasarkan komoditinya. Ada empat petani menjual bawang merah lansung kepada pedagang pengecer, lima belas petani menjual bawang merah kepada pedagang pengumpul desa, dan enam petani menjual bawang merah kepada pedagang besar desa.

2) Pedagang pengumpul

Pedagang yang melakukan aktivitas membeli bawang merah dari petani untuk kemudian dijual kepada pedagang pengecer. Hasil penelitian menunjukkan bahwa terdapat sepuluh pedagang pengumpul yang berada di Desa Tonsewer Selatan, membeli bawang merah dari petani untuk dijual kepada pedagang pengecer di pasar Tomohon.

3) Pedagang besar

Pedagang yang membeli bawang merah dari produsen (petani) lalu dikumpulkan kemudian menjualnya. Hasil penelitian menunjukkan bahwa hanya ada satu pedagang besar yang membeli bawang merah lansung dari petani kemudian mendistribusikan ke pelabuhan Pomako Timika melalui pelabuhan Bitung.

4) Pedagang pengecer

Pedagang yang membeli bawang merah dari petani dan pedagang pengumpul kemudian menjualnya kepada konsumen. Hasil penelitian menunjukkan ada enam belas pedagang pengecer dimana ada empat pedagang pengecer yang menjual di pasar Kawangkoan,dua pedagang pengecer yang menjual bawang merah di Langowan, dan 
sepuluh pedagang pengecer yang menjual di pasar Tomohon.

5) Konsumen

Orang yang membeli bawang merah dari pedagang pengecer untuk dikonsumsi.

\section{Saluran Pemasaran Bawang Merah di Desa Tonsewer Selatan}

Saluran pemasaran bawang merah adalah rangkaian lembaga-lembaga pemasaran yang dilalui dalam penyaluran dari petani ke konsumen akhir. Penyaluran hasil produksi dari petani ke konsumen melalui lebih dari satu saluran pemasaran, dimana masing-masing saluran melibatkan lembaga pemasaran yang berbeda.

Saluran pemasaran dapat dipilih secara bebas, artinya mereka dapat memilih saluran pemasaran yang mana paling menguntungkan. Berdasarkan hasil penelitian yang telah dilaksanakan, dapat diketahui bahwa pola saluran pemasaran bawang merah di Desa Tonsewer Selatan Kecamatan Tompaso Barat adalah sebagai berikut:

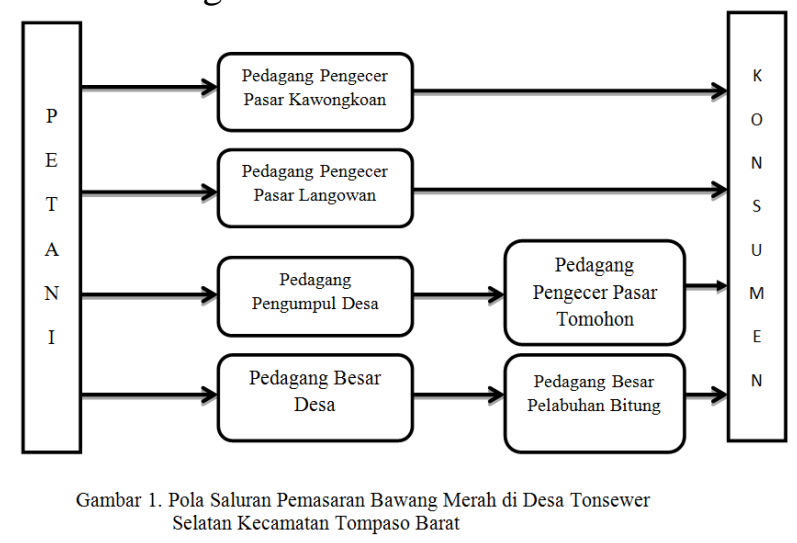

Hasil penelitian menunjukkan terdapat empat saluran pemasaran bawang merah dari Desa Tonsewer Selatan Kecamatan Tompaso Barat yaitu :

1. Saluran pemasaran I

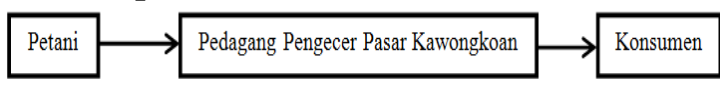

Dengan sistem ini produsen (petani) lansung menjual bawang merah kepada pedagang pengecer di pasar Kawangkoan dengan pertimbangan petani ingin memperoleh harga jual yang tinggi dibandingkan petani menjual kepada pedagang pengumpul desa. Disamping itu, antara petani bawang merah dan pedagang pengecer sudah terjalin kerjasama sehingga berapun jumlah bawang merah petani akan dibeli oleh pedagang pengecer. Saluran ini biasa ditempuh oleh petani yang memiliki lahan yang sempit sehingga produksinya sedikit.

2. Saluran pemasaran II

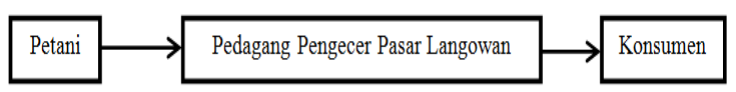

Dengan sistem ini produsen (petani) lansung menjual bawang merah kepada pedagang pengecer di pasar Langowan dengan pertimbangan petani ingin memperoleh harga jual yang tinggi dibandingkan petani menjual kepada pedagang pengumpul desa. Namun jumlah bawang merah yang di jual lebih sedikit dibandingkan pada saluran pemasaran I, hal ini disebabkan masuknya bawang merah kanvas yang berasal dari Jawa dalam jumlah besar, sehingga menyebabkan persaingan dagang antara bawang merah jenis "Lansuna" yang bersumber dari Tonsewer Selatan dan bawang merah varietas Bima berasal dari Brebes Jawa Barat.

3. Saluran pemasaran III

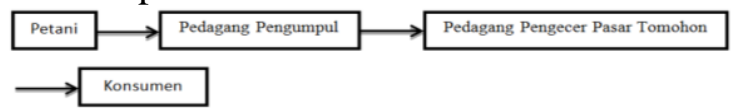

Pada saluran III ini petani menjual bawang merah kepada pedagang pengumpul desa. Hal ini dilakukan karena pedagang pengumpul lansung datang kerumah petani untuk membeli bawang merah untuk dijual kepada pedagang pengecer di pasar Tomohon. Dalam hal ini pedagang pengumpulsifatnya kekeluargaan dengan petani bawang merah sehingga harga yang ditawarkan masih rendah. Disamping itu, alasan petani melakukan sistem saluran pemasaran ini karena mempertimbangkan biaya dan waktu, seperti biaya angkutan ke pasar Tomohon yang cukup besar.

4. Saluran pemasaran IV

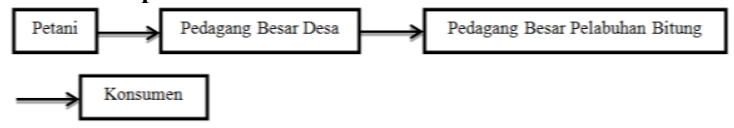

Pada saluran pemasaran ini petani menjual bawang merah kepada pedagang besar desa kemudian pedagang besar menjualnya ke pelabuhan Pomako Timika melalui 
pelabuhan Bitung. Hal ini dilakukan apabila ada permintaan bawang merah dari luar pulau. Dalam hal ini pedagang besar sifatnya masih kekeluargaan sehingga berapapun jumlah bawang merah yang dijual oleh petani akan dibeli oleh pedagang besar dengan penentuan harga negosiasi. Disamping itu jumlah bawang merah yang dijual oleh petani dalam jumlah yang banyak menjadi alasan melakukan saluran pemasaran IV.

\section{Analisis Elastisitas Transmisi Harga}

Elastisitas transmisi harga merupakan perbandingan perubahan harga bawang merah ditingkat pedagang dengan perubahan harga ditingkat petani. Besar elastisitas transmisi harga pada setiap saluran pemasaran dapat dilihat pada Tabel 9.

\begin{tabular}{lcccc}
\multicolumn{5}{c}{ Tabel 9. Elastisitas Transmisi Harga Pada Setiap Saluran Pemasaran } \\
\hline \multicolumn{1}{c}{$\begin{array}{c}\text { Saluran } \\
\text { Pemasaran }\end{array}$} & $\begin{array}{c}\text { Harga Tingkat } \\
\text { Petani } \\
(\mathrm{Rp} / \mathrm{Kg})\end{array}$ & $\begin{array}{c}\text { Harga Tingkat } \\
\text { Konsumen } \\
(\mathrm{Rp} / \mathrm{Kg})\end{array}$ & $\begin{array}{c}\text { Koefisien } \\
\text { Regresi }\end{array}$ & $\begin{array}{c}\text { Elastisitas } \\
\text { Transmisi } \\
\text { Harga }\end{array}$ \\
\hline $\begin{array}{l}\text { Saluran } \\
\text { Pemasaran I }\end{array}$ & 18.500 & 22.625 & 0,82 & 0,99 \\
$\begin{array}{l}\text { Saluran } \\
\text { pemasaran II }\end{array}$ & 18.000 & 22.250 & 0,94 & 0,86 \\
$\begin{array}{l}\text { Saluran } \\
\text { Pemasaran III }\end{array}$ & $14.066,6$ & 22.000 & 1,11 & 0,57 \\
$\begin{array}{l}\text { Saluran } \\
\text { Pemasaran IV }\end{array}$ & 16.000 & 40.000 & 1,06 & 0,38 \\
\hline
\end{tabular}

Sumber : Data Primer yang Diolah, 2017

Tabel 9 menunjukkan bahwa, system pemasaran bawang merah dari pusat Desa Tonsewer Selatan ke daerah pusat konsumen Kawangkoan, Langowan, Tomohon dan Pelabuhan Pomako Timika tidak efesien. Hal tersebut ditunjukkan dengan nilai elastisitas transmisi harga dalam sistem pemasaran bawang merah dari daerah pusat produksi Desa Tonsewer Selatan ke daerah pusat konsumen Kawangkoan $\mathrm{Et}=0,99$ persen, ke daerah pusat konsumen Langowan $\mathrm{Et}=0,86$ persen, ke daerah pusat konsumen Tomohon $\mathrm{Et}=0,57$ persen, dan daerah pusat pelabuhan Pomako Timika $\mathrm{Et}=0,38$ persen. Hal ini berarti bahwa produsen bawang merah di daerah pusat produksi menghadapi pasar persaingan tidak sempurna dan struktur pasar tidak berintegrasi.

\section{Margin Pemasaran}

Berdasarkan hasil penelitian diketahui bahwa ada empat jenis saluran pemasaran bawang merah yang terjadi di Desa Tonsewer Selatan. Dengan adanya perbedaan jumlah lembaga pemasaran yang terlibat pada setiap saluran pemasaran menyebabkan margin pemasaran berbeda. Margin yang terdiri atas biaya pemasaran yang bervariasi antara saluran pemasaran yang satu dengan saluran pemasaran lainnya, perbedaan biaya pemasaran yang harus dikeluarkan lembagalembaga pemasaran akan menyebabkan perbedaan harga, karena masing-masing berusaha untuk memperoleh keuntungan dari proses pemasaran tersebut. Besarnya biaya yang dikeluarkan oleh lembaga pemasaran pada saluran pemasaran I dapat dilihat pada Tabel 10.

\begin{tabular}{|c|c|c|}
\hline Komponen Biaya & Harga $(\mathrm{Rp} / \mathrm{Kg})$ & Share $(\%)$ \\
\hline Harga Jual Petani & 18.500 & 81,76 \\
\hline \multicolumn{3}{|l|}{ Biaya Pemasaran: } \\
\hline 1. Pembersihan & 500 & 2,20 \\
\hline 2. Penjemuran Dan Pengeringan & 200 & 0,80 \\
\hline 3. Pengemasan & 60 & 0,26 \\
\hline 4. Biaya Sortasi Dan Pengepakan & 200 & 0,80 \\
\hline 5. Pengangkutan & 125 & 0,55 \\
\hline 6. Retribusi & 450 & 1,98 \\
\hline Total Biaya & 1.535 & 6,78 \\
\hline Keuntungan & 16.965 & 74,98 \\
\hline Harga Jual Pedagang Pengecer & 22.625 & \\
\hline \multicolumn{3}{|l|}{ Biaya Pemasaran: } \\
\hline 7. Kemasan Kantong Plastik & 66,6 & 0.29 \\
\hline 8. Retribusi & 450 & 1,98 \\
\hline 9. Penyimpanan & 0,40 & 0,001 \\
\hline Total Biaya & 517 & 2,28 \\
\hline Keuntungan & 3.608 & 15,94 \\
\hline Margin & 4.125 & 18,23 \\
\hline Harga Beli Konsumen Akhir & 22.625 & 100 \\
\hline
\end{tabular}

Tabel 10 menunjukkan share yang diterima petani adalah 81,86 persen. biaya yang dikeluarkan oleh pedagang pengecer yaitu sebesar Rp.517 atau 2,28 persen. Margin pemasaran adalah Rp.4.125 atau 18,23 persen dan keuntungan pedagang pengecer sebesar Rp.3.608 atau 15,94 persen. Petani menjual bawang merah lansung kepada pedagang pengecer di pasar Kawangkoan sehingga petani menanggung biaya angkutan dan biaya pengemasan untuk menyampaikan bawang merah kepada pedagang pengecer. 


\begin{tabular}{|c|c|c|}
\hline & & \\
\hline Harga jual petani & 18.000 & 80,89 \\
\hline \multicolumn{3}{|l|}{ Biaya pemasaran: } \\
\hline 1. Pembersihan & 500 & 2,24 \\
\hline $\begin{array}{l}\text { 2. Penjemuran dan } \\
\text { pengeringan }\end{array}$ & 200 & 0,89 \\
\hline 3. Kemasan & 60 & 0,26 \\
\hline $\begin{array}{l}\text { 4. Biaya sortasi dan } \\
\text { pengepakan }\end{array}$ & 200 & 0,89 \\
\hline 5. Pengangkutan & 125 & 0,56 \\
\hline 6. Retribusi & 450 & 2,02 \\
\hline Total biaya & 1.535 & 6,89 \\
\hline Keuntungan & 16.465 & 74,00 \\
\hline Harga jual pedagang pengecer & & \\
\hline kepada konsumen & 22.250 & \\
\hline \multicolumn{3}{|l|}{ Biaya pemasaran: } \\
\hline 7. Kemasan kantong plastic & 66.6 & 0,29 \\
\hline 8. Retribusi & 450 & 2,02 \\
\hline 9. Penyimpanan & 0.4 & 0,001 \\
\hline Total biaya & 517 & 2,32 \\
\hline Keuntungan & 3.733 & 16,77 \\
\hline Margin & 4.250 & 19,10 \\
\hline Harga beli konsumen akhir & 22.250 & 100 \\
\hline
\end{tabular}

Tabel 11 menunjukkan bahwa total biaya pemasaran yang dikeluarkan oleh petani adalah Rp.1.535 atau 6,89 persen sedangkan total biaya yang dikeluarkan oleh pedagang pengecer yaitu sebesar Rp.517 atau 2,32 persen. Dengan margin pemasaran sebesar Rp. 4.250 atau 19,10 persen dan keuntungan pedagang pengecer sebesar Rp.3.733 atau 16,77 persen. Petani menjual bawang merah lansung kepada pedagang pengecer di pasar Langowan sehingga petani menanggung biaya angkutan dan biaya pengemasan untuk menyampaikan bawang merah kepada pedagang pengecer.

\begin{tabular}{lcc} 
Tabel 12. Komponen Biaya, Keuntungan, Margin Pemasaran dan Share \\
\multicolumn{3}{c}{$\begin{array}{c}\text { Bawang Merah Pada Saluran Pemasaran III Dari Pusat Produksi } \\
\text { Desa Tonsewer Selatan Ke Pusat Konsumen Pasar Tomohon }\end{array}$} \\
\hline Komponen Biaya & Harga (Rp/Kg) & Share $(\%)$ \\
\hline Harga Jual Petani & $14.066,6$ & 63,93 \\
Biaya Pemasaran: & & \\
1. Pembersihan & 500 & 2,27 \\
2. Penjemuran dan Pengeringan & 200 & 0,90 \\
3. Biaya Sortasi dan Pengepakan & 200 & 0,90 \\
Total Biaya & 900 & 4,09 \\
Keuntungan & 13.166 & 59,84 \\
Harga Jual Pedagang Pengumpul & 16.950 & \\
Biaya Pemasaran: & & \\
$\quad$ 4. Pengangkutan I & 50 & 0,22 \\
5. Pengangkutan II & 200 & 0,90 \\
6. pengemasan & 60 & 0,27 \\
7. Retribusi & 650 & 2,95 \\
Total Biaya & 960 & 4,36 \\
Keuntungan & $1.923,4$ & 8,74 \\
Margin & $2.883,4$ & 13,10 \\
Harga jual pedagang pengecer & 22.000 & \\
Biaya Pemasaran: & & \\
8. Kemasan & 80 & 0,36 \\
9. Retribusi & 650 & 2,95 \\
10. Penyimpanan & 0,59 & 0,002 \\
Total Biaya & 717,19 & 3,25 \\
Keuntungan & $4.322,8$ & 19,69 \\
Margin & 5.050 & 22,95 \\
\hline Harga Beli Konsumen Akhir & 22.000 & 100 \\
\hline S & &
\end{tabular}

Sumber : Data Primer yang Diolah, 2017
Tabel 12 menunjukkan bahwa total biaya pemasaran oleh pedagang pengumpul Rp.960 atau 4,36 persen sedangkan biaya yang dikeluarkan oleh pedagang pengecer pasar Tomohon Rp.717,19 atau 3,25 persen. Total biaya pemasaran lebih besar berada ditingkat pedagang pengumpul, disebabkan oleh biaya pengangkutan untuk transportasi bawang merah dari petani dan pedagang pengecer, Pengangkutan bawang merah dilakukan dengan menggunakan mobil pick up dengan muatan berbagai macam hasil lainnya seperti tomat dan sayuran.

Keuntungan yang diperoleh pedagang pengumpul sebesar Rp.1.923,4 atau 8,74 persen dan pedagang pengecer mendapatkan keuntungan sebesar Rp.4.332,8 atau 19,69 persen. Pedagang pengecer hanya mengeluarkan biaya pengemasan, retribusi dan penyimpanan sehingga keuntungan yang diperoleh jauh lebih besar dari pedagang pengumpul. Margin pemasaran tertinggi berada ditingkat pedagang pengecer yaitu Rp.5.050 atau 22,95 persen.

\begin{tabular}{lcc}
$\begin{array}{l}\text { Tabel 13. Komponen Biaya, Keuntungan, Margin Pemasaran dan Share } \\
\text { Bawang Merah Pada Saluran Pemasaran IV dari Pusat Produksi } \\
\text { Desa Tonsewer Selatan Ke pelabuhan Pomako }\end{array}$ \\
\hline Komponen Biaya & Harga (Rp/Kg) & Share $(\%)$ \\
\hline Petani & 16.000 & 40.00 \\
Biaya Pemasaran: & & \\
1. Pembersihan & 500 & 1.25 \\
2. Penjemuran Dan Pengeringan & 200 & 0.5 \\
3. Sortasi Dan Pengepakan & 200 & 0.5 \\
Total Biaya & 900 & 2.25 \\
Keuntungan & 15100 & 37.75 \\
Harga Jual Petani & 16.000 & 40 \\
Harga Jual Pedagang Besar & 40.000 & \\
Biaya Pemasaran: & & \\
4. Pengangkutan I & 40 & 0.1 \\
5. Pengangkutan II & 300 & 0.75 \\
6. Pengangkutan III & 2400 & 6,0 \\
7. Sortasi dan Pengepakan & 160 & 0,4 \\
7. Bongkar Muat & 600 & 1,5 \\
8. Kemasan & 60 & 0,15 \\
Total Biaya & 3.560 & 8,9 \\
Keuntungan & 20.440 & 51,1 \\
Margin & 24.000 & 60 \\
\hline Sumber : Data Primer yang Diolah, 2017 & &
\end{tabular}

Tabel 13 menunjukan biaya pemasaran yang dikeluarkan pedagang besar yaitu sebesar Rp.3.560 atau 8,9. Pedagang besar mengeluarkan biaya yang besar karena jarak dari titik produksi bawang merah ke titik konsumen cukup jauh sehingga pengangkutan dilakukan sebanyak tiga kali dengan biaya transportasi yang besar. Total keuntungan yang diperoleh pedagang besar yaitu sebesar 
Rp.20.440 atau 51,1 dengan margin pemasaran Rp.24.000 atau 60 persen.

Berdasarkan hasil analisis margin, pola saluran pemasaran merupakan pola saluran yang relative efesien, karena memiliki margin paling kecil yaitu sebesar Rp.4.583,3 atau 20,52 persen dari harga jual ditingkat pedagang pengecer. Hal ini disebabkan produsen (petani) lansung menjual bawang merah ke pasar kawangkoan dan langowan, sehingga tidak melibatkan banyak lembaga pemasaran yang dapat menambah biaya pemasaran.

\section{Farmer's Share}

Farmer's share berhubungan negatif dengan margin pemasaran, artinya semakin tinggi margin pemasaran maka bagian yang diterima petani akan semakin rendah. Farmer's share yang diterima petani pada saluran pemasaran bawang merah di Desa Tonsewer Selatan dapat dilihat pada Tabel 14.

\begin{tabular}{|c|c|c|c|}
\hline & $\begin{array}{l}\text { verSelatan Kec } \\
\text { asa }\end{array}$ & Tompaso & Kabupater \\
\hline $\begin{array}{c}\text { Saluran } \\
\text { Pemasaran }\end{array}$ & $\begin{array}{l}\text { Harga di Tingkat } \\
\text { Petani }(\mathrm{Rp} / \mathrm{Kg})\end{array}$ & $\begin{array}{c}\text { Harga ditingkat } \\
\text { Konsumen }(\mathrm{Rp} / \mathrm{Kg})\end{array}$ & $\begin{array}{c}\text { Farmer's Share } \\
(\%)\end{array}$ \\
\hline Pola I & 18.500 & 22.625 & 81,76 \\
\hline Pola II & 18.000 & 22.250 & 80,89 \\
\hline Pola III & $14.066,6$ & 22.000 & 63,93 \\
\hline Pola IV & 16.000 & 40.000 & 40,00 \\
\hline
\end{tabular}

Tabel 14 menunjukkan bahwa farmer's share yang diterima petani pada pola saluran pemasaran I yaitu sebesar 81,76 persen artinya bahwa bagian yang diterima oleh petani sebesar 81,76 persen dari harga yang dibayarkan oleh konsumen akhir. Pada pola pemasaran II farmer's share yang diterima adalah 80,89 persen sedangkan pada pola pemasaran III yaitu sebesar 63,93 dan pada pola saluran pemasaran IV yaitu sebesar 40,00. Pola saluran pemasaran IV memiliki farmer's share terkecil diantara pola saluran pemasaran lainnya karena pola pemasaran ini merupakan pola pemasaran terpanjang jika dilihat dari jumlah lembaga pemasaran yang terlibat dan daerah tujuan penjualan. Pola saluran pemasaran I merupakan pola saluran pemasaran dengan farmer's share tertinggi dibandingkan dengan pola saluran pemasaran lainnya. Hal ini disebabkan oleh karena pola saluran pemasaran I adalah pola saluran pemasaran terpendek jika dilihat dari jumlah lembaga pemasaran yang terlibat dan tujuan penjualan. Dari farmer's share tersebut terlihat bahwa pola saluran pemasaran I merupakan pola saluran yang menguntungkan bagi petani karena memiliki nilai farmer's share terbesar.

\section{Rasio Keuntungan Terhadap Biaya}

Rasio keuntungan terhadap biaya digunakan untuk mengetahui penyebaran rasio keuntungan terhadap biaya yang diperoleh pada masing-masing lembaga pemasaran yang terlibat pada setiap saluran pemasaran. Biaya pemasaran merupakan keseluruhan biaya yang dikeluarkan oleh lembaga pemasaran yang terlibat dalam penyaluran bawang merah dari tingkat petani hingga ke konsumen akhir yang dinyatakan dalam satuan rupiah per $\mathrm{kg}$ sedangkan keuntungan pemasaran merupakan selisih antara margin pemasaran dengan biaya pemasaran yang dikeluarkan selama proses pemasaran. untuk rasio keuntungan terhadap biaya pada komoditi bawang merah di Desa Tonsewer Selatan dapat dilihat pada Tabel 15.

\begin{tabular}{|c|c|c|c|c|}
\hline \multirow{2}{*}{ Lembaga Pemasaran } & \multicolumn{4}{|c|}{ Saluran Pemasaran } \\
\hline & 1 & 2 & 3 & 4 \\
\hline Pedagang Pengumpul & & & 2,03 & \\
\hline Pedagang Besar & & & & 5,74 \\
\hline Pedagang Pengecer & 6,97 & 7,22 & 6,02 & \\
\hline
\end{tabular}

Tabel 15 menunjukkan bahwa pada pola saluran pemasaran I rasio keuntungan terhadap biaya pemasaran diperoleh pedagang pengecer yaitu sebesar 6,97 persen. Pada pola saluran pemasaran II rasio keuntungan terhadap biaya diperoleh pedagang pengecer yaitu sebesar 7,22 persen sedangkan pada pola saluran pemasaran III rasio keuntungan terhadap biaya pemasaran diperoleh pedagang pengecer yaitu sebesar 6,02 persen dan pada pola saluran pemasaran IV memperoleh nilai sebesar 5,74 pada pedagang besar.Oleh karena itu pemasaran bawang merah di Desa Tonsewer Selatan tidak memberikan keuntungan yang merata pada setiap saluran pemasaran yang terlibat.

Berdasarkan nilai rasio keuntungan terhadap biaya pemasaran pola saluran pemasaran II memiliki nilai rasio tertinggi 
dibandingkan saluran pemasaran lainnya, hal ini disebabkan biaya pemasaran yang dikeluarkan oleh pedagang pengecer pada saluran pemasaran I lebih kecil dengan keuntungan yang cukup besar.

\section{Efesiensi Pemasaran}

Efesiensi adalah suatu sistem pemasaran yang mampu melakukan pembagian yang adil dari keseluruhan harga yang dibayarkan konsumen akhir kepada semua pihak yang telah ikut serta didalam produksi dan pemasaran komoditas pertanian (Mubyarto, 1989). Efesiensi pemasaran dapat diukur dengan membandingkan nilai elastisitas transmisi harga, margin pemasaran, farmer's share dan rasio keuntungan terhadap biaya (Anindita, 2017). Nilai efisiensi pemasaran pada saluran pemasaran bawang merah di Desa Tonsewer Selatan Kecamatan Tompaso Barat dapat dilihat pada Tabel 16.

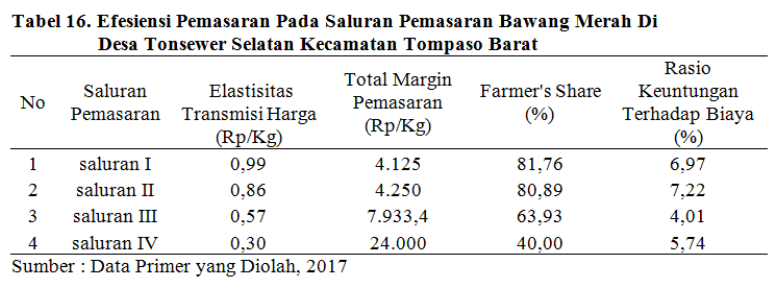

Tabel 16 menunjukkan bahwa nilai elastisitas transmisi harga lebih kecil dari satu sehingga laju perubahan harga bawang merah ditingkat petani lebih kecil daripada laju perubahan harga ditingkat konsumen. Oleh karena itu pemasaran bawang merah di Desa Tonsewer Selatan tidak efesien.

Total margin pemasaran yang terdapat memiliki nilai yang tidak merata, karena dalam aktivitas pemindahan bawang merah dari petani kepada konsumen memiliki jarak yang berbedabeda. Pada saluran pemasaran empat menempuh jarak yang lebih jauh dibandingkan pada saluran pemasaran satu, dua, dan tiga. Hal tersebut menyebabkan saluran pemasaran empat lebih panjang dan melibatkan banyak lembaga pemasaran sehingga harga bawang tinggi di tingkat konsumen, namun harga bawang merah ditingkat petani tidak ikut mengalami perubahan. Sehingga margin pemasaran pada saluran pemasaran empat lebih besar daripada saluran pemasaran lainnya.
Pada saluran pemasaran empat memiliki nilai farmer's share yang kurang dari 50\% sehingga saluran pemasaran empat tidak efesien. Hal ini disebabkan bagian harga yang diterima petani lebih kecil daripada saluran pemasaran lainnya. Rasio keuntungan terhadap biaya tidak efesien karena nilai rasio tidak merata.

\section{KESIMPULAN DAN SARAN}

\section{Kesimpulan}

1. Terdapat empat saluran pemasaran yang terjadi di Desa Tonsewer Selatan Kecamatan Tompaso Barat Kabupaten Minahasa yaitu saluran pemasaran pertama terjadi dari Desa Tonsewer Selatan ke pasar Kawangkoan, saluran pemasaran kedua terjadi dari Desa Tonsewer Selatan ke pasar Langowan, saluran pemasaran ketiga terbentuk dari Desa Tonsewer Selatan sampai ke pasar Tomohon, dan saluran ke empat terjadi dari Desa Tonsewer Selatan ke pedagang besar pelabuhan Bitung.

2. Berdasarkan nilai elastisitas transmisi harga, margin pemasaran, farmer's share, dan rasio keuntungan terhadap biaya menunjukkan bahwa saluran pemasaran empat tidak efesien. saluran pemasaran satu efesien berdasarkan nilai elastisitas transmisi harga, margin pemasaran, dan farmer's share, saluran pemasaran dua efesien berdasarkan farmer's share dan rasio keuntungan terhadap biaya, dan saluran pemasaran tiga efesien pada farmer's share.

\section{Saran}

1. Pola saluran pemasaran yang dipilih oleh masing-masing lembaga pemasaran sebaiknya disesuaikan dengan kondisi dan kebutuhan lembaga pemasaran.

2. Harus adanya peran dari pemerintah dalam pengembangan pemasaran bawang merah, khususnya dalam mengusahakan sarana informasi harga bagi petani dalam kegiatan pemasaran bawang merah. 


\section{DAFTAR PUSTAKA}

Abubakar, I. 2016. Analisis Structure, Conduct And Performance Pada Pasar Kakao: Kasus Di Kabupaten Parigi Moutong Provinsi Sulawesi Tengah. Tesis. Institut Pertanian Bogor. Bogor.

Anindita, R. 2017. Pemasaran Produk Pertanian. Penerbit Andi. Yogyakarta.

Azzaino, Z. 1987. Pengantar Tataniaga Pertanian. Departemen Ilmu-Ilmu Sosial Ekonomi Pertanian. Fakultas pertanian. Institut Pertanian Bogor. Bogor.

Badan Pusat Statistika. 2016. Luas lahan Dan Produksi Bawang Merah di Kabupaten Minahasa. Tondano.

Cahyono, B. 1996. Intensifikasi Budidaya Bawang Merah. Penerbit Kanisius. Yogyakarta.

Gasprez, Vincent. 2001. Ekonomi Manajerial Pembuatan Keputusan Bisnis. PT. Gramedia Pustaka Utama. Jakarta.

Hanafie, R. 2010. Pengantar Ekonomi Pertanian. C.V Andi Offset. Yogyakarta.

Hasyim, A.I. 2003. Tataniaga Pertanian. Diktat Kuliah. Fakultas Pertanian. Universitas Lampung. Bandar Lampung.

Kusnadi N., Anna F., Dwi R., Siti J. 2009. Bunga Rampai Agribisnis. Seri Pemasaran. Departemen Agribisnis. Fakultas Ekonomi Dan Manejemen. Institut Pertanian Bogor. Bogor.

Mubyarto. 1989. Pengantar Ilmu Pertanian. LP3ES. Jakarta.

Nitasari, Devi. 2010. Analisis Pendapatan Usahatani Dan Tataniaga Tembakau Voor Oogst Kasturi Pada Gabungan Kelompok Tani Permata Vii Desa Pakusari, Kecamatan Pakusari,

Kabupaten Jember, Provinsi Jawa Timur. Skripsi. Fakultas Ekonomi Dan Manajemen. Institut Pertanian Bogor. Bogor.
Rahmawati Andita. 2013. Analisis Efisiensi Pemasaran Nenas Studi Kasus Di Desa Cipelang, Kecamatan Cijeruk, Kabupaten Bogor. Skripsi. Fakultas Ekonomi Dan Manajemen. Institut Pertanian Bogor. Bogor.

Ramadhani D.K. 2013. Analisis Efisiensi Pemasaran Jagung Zea Mays Di Kabupaten Grobogan Studi Kasus Di Kecamatan Geyer. Skripsi. Fakultas Pertanian. Universitas Sebelas Maret. Surakarta.

Roesmawati, H. 2011. "Analisis Efisiensi Pemasaran Pisang Produksi Petani Di Kecamatan Lengkiti Kabupaten Ogan Komering Ulu", Jurnal Agrobisnis, Vol. 3, No. 5:78-79.

Santoso I.T. 2014. "Efisiensi Pemasaran Beberapa Komoditas Sayuran Utama Di Kabupaten Indramayu", Jurnal Agri Wiralodra, Vol. 6, No.2:49-52.

Sudarmanto. 2016. Pemasaran Bawang Merah. Delta Media. Surakarta.

Soekartawi. 2002. Prinsip Dasar Manajemen Pemasaran Hasil-hasil Pertanian. PT. Raja Grafindo Persada. Jakarta.

Suherty Lina. 2009. "Analisis Efisiensi Pemasaran Jeruk. Studi Kasus Di Desa Karang Dukuh, Kecamatan Belawang Barito Kuala, Kalimantan Selatan”. Jurnal Agritek. Vol. 17, No.6: 52-53.

Thomas, H. H. 2012, Sistem Manajemen Lembaga Pemasaran Komoditi Sayuran Wortel Daucus carota L di Kelurahan Rurukan Kecamatan Tomohon Timur. Tesis. Program Pascasarjana. Universitas Sam Ratulangi. Manado.

Wacana Anita. 2011. Analisis Tataniaga Bawang Merah Studi Kasus Di Kelurahan Brebes, Kecamatan Brebes, Kabupaten Brebes. Skripsi. Fakultas Ekonomi Dan Manajemen. Institut Pertanian Bogor. Bogor. 